\title{
G protein-coupled estrogen receptor (version 2019.4) in the IUPHAR/BPS Guide to Pharmacology Database
}

\author{
Edward Filardo ${ }^{1}$, Richard Neubig ${ }^{2}$ and Eric R. Prossnitz ${ }^{3}$ \\ 1. Rhode Island Hospital, USA \\ 2. Michigan State University, USA \\ 3. University of New Mexico, USA
}

\begin{abstract}
The G protein-coupled estrogen receptor (GPER, nomenclature as agreed by the NC-IUPHAR

Subcommittee on the G protein-coupled estrogen receptor [24]) was identified following observations of estrogen-evoked cyclic AMP signalling in breast cancer cells R], which mirrored the differential expression of an orphan 7-transmembrane receptor GPR30 [5]. There are observations of both cell-surface and intracellular expression of the GPER receptor [27, 32]. Selective agonist/ antagonists for GPER have been characterized [24]. Antagonists of the nuclear estrogen receptor, such asfulvestrant [10], tamoxifen [27, 32] and raloxifene [23], as well as the flavonoid 'phytoestrogens'genistein and quercetin [16], are agonists of GPER. A complete review of GPER pharmacology has been recently published [24]. The roles of GPER in physiological systems throughout the body (cardiovascular, metabolic, endocrine, immune, reproductive) and in cancer have also been reviewed $[24,25,18,15,8]$.
\end{abstract}

\section{Contents}

This is a citation summary for G protein-coupled estrogen receptor in the Guide to Pharmacology database (GtoPdb). It exists purely as an adjunct to the database to facilitate the recognition of citations to and from the database by citation analyzers. Readers will almost certainly want to visit the relevant sections of the database which are given here under database links.

GtoPdb is an expert-driven guide to pharmacological targets and the substances that act on them. GtoPdb is a reference work which is most usefully represented as an on-line database. As in any publication this work should be appropriately cited, and the papers it cites should also be recognized. This document provides a citation for the relevant parts of the database, and also provides a reference list for the research cited by those parts.

Please note that the database version for the citations given in GtoPdb are to the most recent preceding version in which the family or its subfamilies and targets were substantially changed. The links below are to the current version. If you need to consult the cited version, rather than the most recent version, please contact the GtoPdb curators.

\section{Database links}

G protein-coupled estrogen receptor 
http://www.guidetopharmacology.org/GRAC/FamilyDisplayForward?familyld=22

Introduction to $\mathrm{G}$ protein-coupled estrogen receptor

http://www.guidetopharmacology.org/GRAC/FamilyIntroductionForward?familyld=22

Receptors

GPER

http://www.guidetopharmacology.org/GRAC/ObjectDisplayForward?objectld=221

\section{References}

1. Albanito L, Madeo A, Lappano R, Vivacqua A, Rago V, Carpino A, Oprea TI, Prossnitz ER, Musti AM and Andò $S$ et al.. (2007) G protein-coupled receptor 30 (GPR30) mediates gene expression changes and growth response to 17beta-estradiol and selective GPR30 ligand G-1 in ovarian cancer cells. Cancer Res. 67: 1859-66 [PMID:17308128]

2. Aronica SM, Kraus WL and Katzenellenbogen BS. (1994) Estrogen action via the cAMP signaling pathway: stimulation of adenylate cyclase and cAMP-regulated gene transcription. Proc. Natl. Acad. Sci. U.S.A.91: 8517-21 [PMID:8078914]

3. Bologa CG, Revankar CM, Young SM, Edwards BS, Arterburn JB, Kiselyov AS, Parker MA, Tkachenko SE, Savchuck NP and Sklar LA et al.. (2006) Virtual and biomolecular screening converge on a selective agonist for GPR30. Nat. Chem. Biol. 2: 207-12 [PMID:16520733]

4. Bonini JA, Anderson SM and Steiner DF. (1997) Molecular cloning and tissue expression of a novel orphan G protein-coupled receptor from rat lung. Biochem. Biophys. Res. Commun. 234: 190-3 [PMID:9168987]

5. Carmeci C, Thompson DA, Ring HZ, Francke $U$ and Weigel RJ. (1997) Identification of a gene (GPR30) with homology to the G-protein-coupled receptor superfamily associated with estrogen receptor expression in breast cancer. Genomics 45: 607-17 [PMID:9367686]

6. Dennis MK, Burai R, Ramesh C, Petrie WK, Alcon SN, Nayak TK, Bologa CG, Leitao A, Brailoiu E and Deliu E et al.. (2009) In vivo effects of a GPR30 antagonistNat. Chem. Biol. 5: 421-7 [PMID:19430488]

7. Dennis MK, Field AS, Burai R, Ramesh C, Petrie WK, Bologa CG, Oprea TI, Yamaguchi Y, Hayashi S and Sklar LA et al.. (2011) Identification of a GPER/GPR30 antagonist with improved estrogen receptor counterselectivity. J. Steroid Biochem. Mol. Biol. 127: 358-66 [PMID:21782022]

8. Filardo EJ. (2018) A role for G-protein coupled estrogen receptor (GPER) in estrogen-induced carcinogenesis: Dysregulated glandular homeostasis, survival and metastasis. J. Steroid Biochem. Mol. Biol. 176: 38-48 [PMID:28595943]

9. Filardo EJ, Graeber CT, Quinn JA, Resnick MB, Giri D, DeLellis RA, Steinhoff MM and Sabo E. (2006) Distribution of GPR30, a seven membrane-spanning estrogen receptor, in primary breast cancer and its association with clinicopathologic determinants of tumor progression. Clin. Cancer Res. 12: 6359-66 [PMID:17085646]

10. Filardo EJ, Quinn JA, Bland KI and Frackelton Jr AR. (2000) Estrogen-induced activation of Erk-1 and Erk2 requires the G protein-coupled receptor homolog, GPR30, and occurs via trans-activation of the epidermal growth factor receptor through release of HB-EGF. Mol. Endocrinol. 14: 1649-60 [PMID:11043579]

11. Filardo EJ, Quinn JA, Frackelton Jr AR and Bland KI. (2002) Estrogen action via the G protein-coupled receptor, GPR30: stimulation of adenylyl cyclase and cAMP-mediated attenuation of the epidermal growth factor receptor-to-MAPK signaling axis. Mol. Endocrinol. 16: 70-84 [PMID:11773440]

12. Gaudet HM, Cheng SB, Christensen EM and Filardo EJ. (2015) The G-protein coupled estrogen receptor, GPER: The inside and inside-out story. Mol. Cell. Endocrinol. 418 Pt 3: 207-19 [PMID:26190834]

13. Isensee J, Meoli L, Zazzu V, Nabzdyk C, Witt H, Soewarto D, Effertz K, Fuchs H, Gailus-Durner V and Busch D et al.. (2009) Expression pattern of $G$ protein-coupled receptor 30 in LacZ reporter mice. Endocrinology 150: 1722-30 [PMID:19095739]

14. Kanda N and Watanabe S. (2003) 17beta-estradiol inhibits oxidative stress-induced apoptosis in keratinocytes by promoting Bcl-2 expression. J. Invest. Dermatol. 121: 1500-9 [PMID:14675202] 
15. Lappano R and Maggiolini M. (2018) GPER is involved in the functional liaison between breast tumor cells and cancer-associated fibroblasts (CAFs). J. Steroid Biochem. Mol. Biol. 176: 49-56 [PMID:28249728]

16. Maggiolini M, Vivacqua A, Fasanella G, Recchia AG, Sisci D, Pezzi V, Montanaro D, Musti AM, Picard D and Andò S. (2004) The G protein-coupled receptor GPR30 mediates c-fos up-regulation by 17betaestradiol and phytoestrogens in breast cancer cells. J. Biol. Chem. 279: 27008-16 [PMID:15090535]

17. Manavathi $B$ and Kumar R. (2006) Steering estrogen signals from the plasma membrane to the nucleus: two sides of the coin. J Cell Physiol 207: 594-604 [PMID:16270355]

18. Meyer MR and Barton M. (2018) GPER blockers as Nox downregulators: A new drug class to target chronic non-communicable diseases. J. Steroid Biochem. Mol. Biol. 176: 82-87 [PMID:28343901]

19. Meyer MR, Fredette NC, Daniel C, Sharma G, Amann K, Arterburn JB, Barton M and Prossnitz ER. (2016) Obligatory role for GPER in cardiovascular aging and disease. Sci Signa/9: ra105 [PMID:27803283]

20. Mårtensson UE, Salehi SA, Windahl S, Gomez MF, Swärd K, Daszkiewicz-Nilsson J, Wendt A, Andersson N, Hellstrand P and Grände PO et al.. (2009) Deletion of the G protein-coupled receptor 30 impairs glucose tolerance, reduces bone growth, increases blood pressure, and eliminates estradiol-stimulated insulin release in female mice. Endocrinology 150: 687-98 [PMID:18845638]

21. O'Dowd BF, Nguyen T, Marchese A, Cheng R, Lynch KR, Heng HH, Kolakowski Jr LF and George SR. (1998) Discovery of three novel G-protein-coupled receptor genes. Genomics 47: 310-3 [PMID:9479505]

22. Owman C, Blay P, Nilsson C and Lolait SJ. (1996) Cloning of human cDNA encoding a novel heptahelix receptor expressed in Burkitt's lymphoma and widely distributed in brain and peripheral tissues. Biochem. Biophys. Res. Commun. 228: 285-92 [PMID:8920907]

23. Petrie WK, Dennis MK, Hu C, Dai D, Arterburn JB, Smith HO, Hathaway HJ and Prossnitz ER. (2013) G protein-coupled estrogen receptor-selective ligands modulate endometrial tumor growth. Obstet Gynecol Int 2013: 472720 [PMID:24379833]

24. Prossnitz ER and Arterburn JB. (2015) International Union of Basic and Clinical Pharmacology. XCVII. G Protein-Coupled Estrogen Receptor and Its Pharmacologic Modulators. Pharmacol. Rev. 67: 505-40 [PMID:26023144]

25. Prossnitz ER and Hathaway HJ. (2015) What have we learned about GPER function in physiology and disease from knockout mice? J. Steroid Biochem. Mol. Biol. 153: 114-26 [PMID:26189910]

26. Quinn JA, Graeber CT, Frackelton Jr AR, Kim M, Schwarzbauer JE and Filardo EJ. (2009) Coordinate regulation of estrogen-mediated fibronectin matrix assembly and epidermal growth factor receptor transactivation by the G protein-coupled receptor, GPR30. Mol. Endocrinol. 23: 1052-64 [PMID:19342448]

27. Revankar CM, Cimino DF, Sklar LA, Arterburn JB and Prossnitz ER. (2005) A transmembrane intracellular estrogen receptor mediates rapid cell signaling. Science 307: 1625-30 [PMID:15705806]

28. Sharma G, Hu C, Brigman JL, Zhu G, Hathaway HJ and Prossnitz ER. (2013) GPER deficiency in male mice results in insulin resistance, dyslipidemia, and a proinflammatory state. Endocrinology 154: 4136-45 [PMID:23970785]

29. Smith HO, Arias-Pulido H, Kuo DY, Howard T, Qualls CR, Lee SJ, Verschraegen CF, Hathaway HJ, Joste NE and Prossnitz ER. (2009) GPR30 predicts poor survival for ovarian cancer. Gynecol. Oncol. 114: 46571 [PMID:19501895]

30. Southern C, Cook JM, Neetoo-Isseljee Z, Taylor DL, Kettleborough CA, Merritt A, Bassoni DL, Raab WJ, Quinn E and Wehrman TS et al.. (2013) Screening $\beta$-Arrestin Recruitment for the Identification of Natural Ligands for Orphan G-Protein-Coupled Receptors. J Biomol Screen 18: 599-609 [PMID:23396314]

31. Terasawa E, Noel SD and Keen KL. (2009) Rapid action of oestrogen in luteinising hormone-releasing hormone neurones: the role of GPR30. J. Neuroendocrinol. 21: 316-21 [PMID:19207808]

32. Thomas P, Pang Y, Filardo EJ and Dong J. (2005) Identity of an estrogen membrane receptor coupled to a G protein in human breast cancer cells. Endocrinology 146: 624-32 [PMID:15539556]

33. Wang C, Dehghani B, Magrisso IJ, Rick EA, Bonhomme E, Cody DB, Elenich LA, Subramanian S, Murphy SJ and Kelly MJ et al.. (2008) GPR30 contributes to estrogen-induced thymic atrophy.Mol. Endocrinol. 22: 636-48 [PMID:18063692]

34. Windahl SH, Andersson N, Chagin AS, Mårtensson UE, Carlsten H, Olde B, Swanson C, Movérare-Skrtic 
S, Sävendahl L and Lagerquist MK et al.. (2009) The role of the G protein-coupled receptor GPR30 in the effects of estrogen in ovariectomized mice. Am. J. Physiol. Endocrinol. Metab. 296: E490-6 [PMID:19088255]

35. Zekas E and Prossnitz ER. (2015) Estrogen-mediated inactivation of FOXO3a by the G protein-coupled estrogen receptor GPER. BMC Cancer 15: 702 [PMID:26470790] 